Creative Commons User License: CC BY-NC-ND

Abstracted by: EBSCOhost, Electronic Journals Service (EJS), Google Scholar, Journal Seek, Scientific Commons,

Food and Agricultural Organization (FAO), CABI and Scopus
Journal of Agricultural Extension

Vol. 23 (4) October, 2019

ISSN(e): 24086851; ISSN(Print); 1119944X

http://journal.aesonnigeria.org

http://www.ajol.info/index.php/iae

Email: editorinchief@aesonnigeria.org

\title{
Impact of the Village Alive Development Initiative on Poverty Reduction Among Farming Households in Kwara State, Nigeria
} https://dx.doi.org/10.4314/jae.v23i4.12

\section{Alalade, Oluwasegun Ayodeji}

Extension Management Division, Department of Rural Development and Gender Issues (RUDEG), Agricultural and Rural Management Training Institute (ARMTI), Ilorin, Nigeria. segunalalade@gmail.com .,Phone: +2347063880416

\section{Longe, Morenike Peju}

Extension Management Division, Department of Rural Development and Gender Issues (RUDEG), Agricultural and Rural Management Training Institute (ARMTI), Ilorin, Nigeria. onikoyipeju@yahoo.com ., Phone: +2348037631394

\section{Popoola, Oluwatoki Peter}

Rural Infrastructure and Institutions Development Division, Department of Rural Development and Gender Issues (RUDEG), Agricultural and Rural Management Training Institute (ARMTI), Ilorin, Nigeria.

oluwatokipeter@yahoo.com .,Phone: +2348065538436

\section{Akinboye, Oyelayo Abisegun}

Department of Agricultural Extension and Rural Development, Ladoke Akintola University of Technology, Ogbomoso, Nigeria. oaakinboye@lautech.edu.ng ., Phone: +2347069597085

\section{Adebisi, Luke Oloruntoba}

General Management Division, Department of Agricultural Development Management, Agricultural and Rural Management Training Institute (ARMTI), llorin, Nigeria. tobadebisi@gmail.com ., Phone: +23407034764622

\begin{abstract}
This paper examined the impact of the Village Alive Development Initiative on poverty reduction in Kwara State, Nigeria. Two hundred and Fourteen (214) farming households were selected from the participating villages in Kwara State. Data were collected using structured interview schedule and were analyzed through the use of frequency count, simple percentages and propensity score matching technique. The results showed that the income level of participating farmers was significantly higher than that of nonparticipants. Furthermore, farm size, years of education and access to loan facilities negatively influence poverty, while, it was also revealed that VADI programme has led to poverty reduction among participating farming household hence such initiative as VADI should be encouraged and sustained among farming households in the study area.
\end{abstract}

Keywords: Poverty, VADI, farming households, impact, income 
Creative Commons User License: CC BY-NC-ND

Abstracted by: EBSCOhost, Electronic Journals Service (EJS), Google Scholar, Journal Seek, Scientific Commons,

Food and Agricultural Organization (FAO), CABI and Scopus
Journal of Agricultural Extension

Vol. 23 (4) October, 2019

ISSN(e): 24086851; ISSN(Print); 1119944X

http://journal.aesonnigeria.org

http://www.ajol.info/index.php/iae

Email: editorinchief@aesonnigeria.org

\section{Introduction}

Staggering poverty in the midst of plenty is one of the world's unsolved issues especially in the developing countries. Poverty has multidimensional nature and can be evident in different forms such as deficiency of material income adequate to guarantee good standard of living; hunger and under-nutrition; illness; limited education and fundamental services; persistent rise in mortality and morbidity due to sickness; homelessness and insufficient housing; insecure environments and social exclusion and discrimination (Ogbeide et. al., 2015). Poverty is the principal cause of hunger and under nourishment. According to the Food and Agriculture Organization (2013), more than 963 million people are hungry and malnourished globally. Most of them are found in the developing countries. Poverty kills about 25000 children each day especially in some of the poorest village of the world (Kakwana, and Subbarao, 2015).

Poverty is a major challenge confronting every nation of the world. World Bank (2015) point out that of the world's 6 billion people, about 2.8 billion lives on less than $\$ 2$ daily and about 1.4 billion live on $\$ 1.9$ per day. It was also estimated that 1.4 billion people had consumption levels below $\$ 1.25$ a day in 2010, while SSA of which Nigeria is one, accounted for 388 million of this number (Global Monitoring Report, 2012).

According to Kolawole and Omobitan (2015), poverty in Nigeria is a paradox. Paradox in sense that, poverty level in Nigeria contradicts the country's abundant wealth of both human and human resources. Simply put, there is poverty in the midst of plenty and inequality in the face of economic growth specifically. However, in the pursuit for a better standard of living of Nigerians, several programmes were introduced and implemented at different periods by different governments such as: Operation Feed the Nation (OFN) of 1977, the green revolution of 1980, Directorate of Foods, Roads and Rural Infrastructure (DFFRI), the National Directorate for Employment (NDE), Poverty Alleviation Programmes (PAP), up to the National Poverty Eradication Programme (NAPEP), Agricultural Development Project (ADP) amongst many others. The chief objective of the programmes amongst other things was to reduce and possibly eliminate poverty and to reduce the inequality between the rich and the poor. In addition, effort has been committed as well by other government agricultural agency in order to attain self-reliance in food production as well as improve food security among poor farmers such as the Village Alive Development Initiative.

The Village Alive Development Initiative (VADI) was initiated by Agricultural and Rural Management Training Institute (ARMTI) as an action oriented research which initially took off in 1995 as Village Alive Women Association (VAWA) in the communities of Idofian, Elerinjare, Jimba-oja and Kabba-owode in Kwara State (VADI, 2018). The intervention of VAWA was aimed at reducing the challenges of women in the selected communities in food processing, value addition and other farming enterprises. It was found out that women were often idle during the dry season and they experience severe food shortage resulting in extreme poverty, low 
Creative Commons User License: CC BY-NC-ND

Abstracted by: EBSCOhost, Electronic Journals Service (EJS), Google Scholar, Journal Seek, Scientific Commons,

Food and Agricultural Organization (FAO), CABI and Scopus
Journal of Agricultural Extension

Vol. 23 (4) October, 2019

ISSN(e): 24086851; ISSN(Print); 1119944X

http://journal.aesonnigeria.org

http://www.ajol.info/index.php/jae

Email: editorinchief@aesonnigeria.org

productivity and the resultant effect was low income and poor standard of living. At the initial stage in 1995, the introduction of VAWA in the communities greatly increased the productivity of community members through improved access to modern farm inputs, extension services, reduction in postharvest losses and enhanced access to credit facilities provided by the project. Unfortunately, the intervention after some years became inactive due to poor funding. ARMTI management resuscitated the project as the Village Alive Development Initiative (VADI) in 2011 and the concept was changed to include Men, Women and Youths as beneficiaries (VADI, 2018).

Nigeria is not only suffering from poverty, income inequality, low income, unstable growth, but also from unemployment, economic instability, political and poor investment (IFAD, 2012). In Nigeria, the scale of poverty has reached an extreme level, in spite of the numerous government poverty alleviation programmes initiated since 1980 till now (IFAD, 2012). Although, the objective of the programmes was among other things to reduce poverty and inequality specifically. However, the interest of poverty reduction is not the rate of growth, but the distribution corrected rate of growth. The importance of inequality for poverty reduction is heavier in the poorest nations of the world, of which Nigeria is not an exception. It is against this background that this study was designed to specifically: examine the poverty status of the participants and non-participants in VADI among the farming households, assess the poverty status and evaluate the impact of the scheme on their poverty reduction in the study area.

\section{Methodology}

The study was carried out in Kwara State, Nigeria. Kwara State lies on latitudes 110 2| and $11045 \mid \mathrm{N}$, and longitude 20 45| and 60 4|E (National Population Commission, 2016). It covers a land area of about $32500 \mathrm{~km} 2$. It is bounded in the north by Niger State, in the south by Oyo, Osun and Ekiti States and in the east by Kogi State. It also has an international boundary in the west with the Republic of Benin. The seasonal pattern of the state is dual; with dry and wet seasons with the wettest months occurring usually between July and September. Monthly rainfall varies between $50.8 \mathrm{~mm}$ and $241.3 \mathrm{~mm}$ levels with the annual mean rainfall between $745.5 \mathrm{~mm}$ and $1,409.2 \mathrm{~mm}$. Average atmosphere temperature is between $180 \mathrm{C}$ and 350C. Kwara state has 24 forest reserves covering 5,087.2sq km (National Population Commission (NPC), 2016).

A multi-stage sampling procedure was employed for the study. The first stage involves a purposive selection of the two local government areas (Ifelodun and Ilorin South) where VADI programme is in operation in Kwara State. The second stage involves a random selection of three (3) communities out of twelve (12) participating communities in Ifelodun LGA while three (3) communities were also selected out of eleven (11) participating communities in Ilorin South LGA. In Ifelodun LGA, Elerinjare, Jimba-oja and Amoyo communities were randomly selected while in llorin South, Fufu, Omomere-oja and Apa-ola communities were randomly selected. The third stage involves a random selection of twenty-five percent $(25 \%)$ from the list of 
Creative Commons User License: CC BY-NC-ND

Abstracted by: EBSCOhost, Electronic Journals Service (EJS), Google Scholar, Journal Seek, Scientific Commons,

Food and Agricultural Organization (FAO), CABI and Scopus
Journal of Agricultural Extension

Vol. 23 (4) October, 2019

ISSN(e): 24086851; ISSN(Print); 1119944X

http://journal.aesonnigeria.org

http://www.ajol.info/index.php/iae

Email: editorinchief@aesonnigeria.org

participants in each of the six (6) selected communities, totalling one hundred and twenty (120) respondents. Also, one hundred and twenty (120) control households that met participants' selection criteria but did not participate in the program were also randomly selected across the communities of interest. Thus, a total number of 120 participants and 120 non-participants were selected for the study. The data for the study were collected using structured interview schedule. Only two hundred and fourteen (214) interview schedules signifying $89.1 \%$ response rate were retrieved and used for the study.

Percentages was used to estimate the socioeconomic characteristics of the respondents while per capita household consumption expenditure was used as a proxy for per capita household income in this study. This was to overcome the problem of overstating or understating household income.

Annual per capita Expenditure = Annual expenditure of households

$$
\text { Household size }
$$

Propensity score matching was used to verify the effect of participation in the programme on poverty reduction.

\section{Average Treatment Effect (ATE)}

In the statistical analysis of observational data, Propensity score matching is a statistical matching technique that attempts to estimate the effect of a treatment, policy, or other intervention by accounting for the covariates that predict receiving the treatment. In other words, propensity score matching can be used. Rosenbaum and Rubin (1983) proposed propensity score matching as a method to reduce the bias in estimating treatment effects with observational datasets. Propensity score matching is a way to evaluate direct causal effects of programs based on the idea that bias is reduced when the outcomes are compared using treated and control subjects who are as similar as possible (Harris, et al., 2015). In literature, one of the most widely used matching method of the propensity score to estimate the ATE is the NearestNeighbour Matching. The average treatment effect shows the difference of a unit (person) being assigned to a particular treatment given a set of observed covariates.

In this study average treatment effect (ATE) method was used to determine the effect of the credit acquisition of the scheme on the participants' poverty reduction. Also, to compare the yield and return on farmland participants and non-participants of the credit acquisition scheme in the study area.

\section{Results and Discussion}

\section{Household Income of Participants and Non-participants}

Table 1 shows the household income of participants and non-participants farmers. The mean income of participants and non-participants was N12305.90 and N5794.21 respectively. This showed that VADI programme significantly impacted on 
Creative Commons User License: CC BY-NC-ND

Abstracted by: EBSCOhost, Electronic Journals Service (EJS), Google Scholar, Journal Seek, Scientific Commons,

Food and Agricultural Organization (FAO), CABI and Scopus
Journal of Agricultural Extension

Vol. 23 (4) October, 2019

ISSN(e): 24086851; ISSN(Print); 1119944X

http://journal.aesonnigeria.org

http://www.ajol.info/index.php/iae

Email: editorinchief@aesonnigeria.org

the mean income of participants as compared to non-participants' farmers. This may be due to the fact that VADI offers several credit schemes that helps farmers access funds for their farm enterprise. When disaggregated by year of education, the result revealed that income increases as year of education increases by both participants and non-participants. However, VADI participants had significantly higher income. This could be because the educated farmers are good adopters of new technologies (Ayinde et. al., 2017). This in turn led to increased yield, and hence more income. This is in consonance with findings by ljioma and Osondu (2015) who showed that income level of rural households increases with increase in education. The result also shows that as farm size cultivated increases, mean income increases with that of VADI participants higher than that of non-participants. This also implies that scale of production affects the mean income of farmers.

Table 1: Level of income by year of education and farm size

\begin{tabular}{llcl}
\hline Characteristics & Score & Participants & Non-participants \\
\hline All & & 12305.90 & 5794.21 \\
Year of Education & $0-5$ & $(3802.45)$ & $(1706.51)$ \\
& & 7742.63 & 1923.61 \\
& $6-11$ & $(2679.42)$ & $(1630.42)$ \\
& & 11457.78 & 3210.31 \\
& & $(1978.42)$ & $(1650.34)$ \\
Farm Size & & 13676.54 & 4545.32 \\
& & $(2005.41)$ & $(1598.54)$ \\
& & 16345.56 & 7967.23 \\
& & $(4567.89)$ & $(2356.67)$ \\
& & 4356.65 & 3978.32 \\
& $3-5$ ha & $(1623.11)$ & $(1634.21)$ \\
& 5234.56 & 4345.76 \\
& & $(1782.89)$ & $(1567.54)$ \\
& & 6979.46 & 4425.12 \\
& & $(1764.57)$ & $(1698.73)$ \\
& & 9345.89 & 4568.68 \\
& & $(1811.12)$ & $(998.32)$ \\
\hline
\end{tabular}

Note: Figures in Parenthesis are standard deviation

Source: Field Survey, 2017 
Creative Commons User License: CC BY-NC-ND

Abstracted by: EBSCOhost, Electronic Journals Service (EJS), Google Scholar, Journal Seek, Scientific Commons,

Food and Agricultural Organization (FAO), CABI and Scopus
Journal of Agricultural Extension

Vol. 23 (4) October, 2019

ISSN(e): 24086851; ISSN(Print); 1119944X

http://journal.aesonnigeria.org

http://www.ajol.info/index.php/jae

Email: editorinchief@aesonnigeria.org

\section{Household Poverty Level}

Poverty lines were computed for respondents using the two-thirds of mean per capita household expenditure. The poverty line is N7263.51 per month. The poverty situation among the respondents is presented in Table 2. Based on the analysis, $38.7 \%$ of VADI participants live below the poverty line while among non-participants, it increased to $62.9 \%$. This shows that non-participants of VADI programme (farmers) tend to be poorer. This attests to the fact that VADI programme significantly increases income level of participants thereby, placing them above the poverty level. Also implicit in this finding is that as year of education increases, poverty reduces among participants and non-participants of VADI programme. Although poverty reduces among respondents as educational attainment advanced, that of participants of VADI programme reduces more than that of non-participants. This again implies that years spent in acquiring formal education affects poverty. In similar vein, as farm size increases, poverty decreases. This is an indication that farmers with small scale of production tend to be poorer when compared with their counterparts that cultivate large farm sizes.

Table 2: Poverty profile by year of education and farm size

\begin{tabular}{lllllccc}
\hline Variable & Score & \multicolumn{2}{l}{ Participants } & \multicolumn{4}{c}{ Non-participants } \\
& & p0 & p1 & p2 & p0 & p1 & p2 \\
\hline All & & 0.4322 & 0.0178 & 0.0001 & 0.4162 & 0.0613 & 0.0089 \\
Years of formal & $0-5$ & 0.3223 & 0.0341 & 0.0025 & 0.5990 & 0.0278 & 0.0029 \\
education & $6-11$ & 0.2100 & 0.0086 & 0.0009 & 0.1322 & 0.0075 & 0.0009 \\
& $12-17$ & 0.1221 & 0.0067 & 0.0007 & 0.0764 & 0.0013 & 0.0000 \\
& $>18$ & 0.0000 & 0.0000 & 0.0000 & 0.0000 & 0.0000 & 0.0000 \\
Farm size & $<2$ & 0.5745 & 0.0164 & 0.0019 & 0.5744 & 0.0099 & 0.0008 \\
& $2-4$ & 0.5422 & 0.0182 & 0.0006 & 0.4231 & 0.0174 & 0.0007 \\
& $>4$ & 0.2264 & 0.0351 & 0.0030 & 0.1765 & 0.0690 & 0.0081 \\
\hline
\end{tabular}

Source: Field Survey, 2017

\section{Effect of VADI's Participation on Poverty Reduction}

The results for average treatment effect are given in Table 4 using the nearest neighbour propensity score matching method with 104 treated VADI's participants against 96 controlled non-VADI's participants. The balancing test was satisfied as well as the common support imposed. The Average treatment effect (ATE) shows that participation in the VADI programme increases the output of the farmers by $5451.74 \mathrm{Kg}$ and was significant at $1 \%$ significant level. The result also shows that participation in VADI programme increases the yield and returns on land of the farmers by $936.18 \mathrm{~kg} / \mathrm{ha}$ and 3174.13 respectively and was significant at $1 \%$ 
Creative Commons User License: CC BY-NC-ND

Abstracted by: EBSCOhost, Electronic Journals Service (EJS), Google Scholar, Journal Seek, Scientific Commons,

Food and Agricultural Organization (FAO), CABI and Scopus
Journal of Agricultural Extension

Vol. 23 (4) October, 2019

ISSN(e): 24086851; ISSN(Print); 1119944X

http://journal.aesonnigeria.org

http://www.ajol.info/index.php/iae

Email: editorinchief@aesonnigeria.org

significant level. Overall, the result shows that the participation in VADI programme has a positive impact on poverty reduction among farmers in the study area.

Table 4: Average treatment estimation of poverty reduction among rural households

\begin{tabular}{llllll}
\hline Variable & Treated & Control & ATE & Standard error & t-statistics \\
\hline Farm size (ha) & 104 & 96 & 0.48 & 0.0410675 & 0.83 \\
Output (kg) & 104 & 96 & 5451.74 & 0.0000512 & $4.93^{\star \star *}$ \\
Yield (ha/kg) & 104 & 96 & 936.18 & 0.0000342 & $6.02^{\star \star *}$ \\
Return on land & 104 & 96 & 3174.13 & 0.0000147 & $5.21^{\star \star *}$ \\
\hline
\end{tabular}

${ }^{*} \mathrm{P} \leq 0.05$

\section{Conclusion and Recommendations}

High level of education and large farm size as well as access to loan helps to raise the farmers' income and their probability of escaping poverty. These support the fact that improvement in education and farm size with credit accessibility can contribute to raising the income of farming households and alleviate poverty in the study area. The policy implication is that farmers' income can be greatly increased through education, access to credit and direct increment of cultivated farm lands. Participation in the VADI credit acquisition scheme has a positive impact on poverty reduction among participating farming households in the study area. Creation of efficient production and market infrastructures, improved extension services, establishment of more agricultural and rural development programmes like VADI scheme to bring about reduction in farmers' poverty level as well as assist farmers in time of inadequacy or loss so that the participants can fully meet up with the continued increase in the cost of living and possibly invest the money in petty trading where they can get more income.

\section{References}

Alalade, O.A. Awoyemi, A.O. Matanmi, B.M. Olaoye, I.J. and Olaitan, T.R. (2017). Farmers' perception of the activities of lower Niger basin authority in llorin east local government area of Kwara state, Nigeria. Journal of Tropical Agriculture, Food, Environment and Extension. Volume 16 Number 2 (May 2017) pp. 17 - 22

Ayinde, O. E; Adejumo A. O; Oloyede A. O; Ibrahim H. K and Ayinde, A. F. O. (2017). Impact of village alive development initiative on farming household's productivity in Kwara State: A comparative analysis. Nigerian Journal of Agricultural Economics (NJAE). Volume 7(1), 2017: Pages 36-44

Global Monitoring Report (2012). Food prices, nutrition and the millennium development goals http://go.worldbank.org. Accessed on 09/06/2016. 
Creative Commons User License: CC BY-NC-ND

Abstracted by: EBSCOhost, Electronic Journals Service (EJS), Google Scholar, Journal Seek, Scientific Commons,

Food and Agricultural Organization (FAO), CABI and Scopus
Journal of Agricultural Extension

Vol. 23 (4) October, 2019

ISSN(e): 24086851; ISSN(Print); 1119944X

http://journal.aesonnigeria.org

http://www.ajol.info/index.php/iae

Email: editorinchief@aesonnigeria.org

ljioma J. C. and Osondu C. K. (2015) Agricultural credit sources and determinants of credit acquisition by farmers in Idemili Local Government Area of Anambra State. Journal of Agricultural Science and Technology B 5 (2015) 34-43.

International Fund for Agricultural Development (IFAD). (2012). Enabling poor rural people to overcome poverty in Nigeria, available at http://www.ifad.org/operations/projects/regions/pa/factsheets/ng.pdf

Harris, J. M., Williams, R. P. and Mishra, A. K. (2015) The Effect of Gender on Productivity Status in U.S. Agriculture, Selected Poster prepared for presentation at the 2015 Agricultural and Applied Economics Association and Western Agricultural Economics Association Joint Meeting, San Francisco, CA July 26-28, 2015.

Kakwana, N and Subbarao, K. (2015). Ageing and poverty in Africa and the role of Social Pensioners, African Human Development, World Bank Washington D.C. March, 2015

Kolawole, B. \&Omobitan, A. (2015). Poverty, inequality and growth in Nigeria: An empirical evidence, Department of Economics, Faculty of Social Sciences, Lagos State University.

National Population Commission (NPC) (2016). National Bureau of Statistics Official Gazatte (FGP 71/52007/2,500(OL24) Abuja. URL http://www.nigerianstat.gov.ng

Ogbeide, O., Nwamaka, E \&Agu, D. (2015). Asian economic and financial review: Poverty and inequality in Nigeria, 5 (3) 439-452. Agro-Science Journal of Tropical Agriculture, Food, Environment and Extension. 15(1) 17-22.

Village Alive Development Initiative (2018). Baseline Survey Report of Village Alive Development Initiative (VADI) carried out in Kwara, Benue, Ebonyi, Nasarawa and Oyo State, Nigeria. An Action Research Project of the Agricultural and Rural Management Training Institute (ARMTI). Pp. 66

World Bank Group (2015). Global Monitoring Report 2014/2015: Ending Poverty and Sharing Prosperity. Washington, DC: World Bank. 244p 